\title{
ÓVODAPEDAGÓGUS-KÉPZÉS FREINET MÓDRA
}

\section{KISSNÉ ZSÁMBOKI RÉKA}

\author{
a Nyugat-magyarországi Egyetem Benedek Elek Pedagógiai Karának \\ tanársegédje \\ kissne.zsamboki.reka@bpk.nyme.hu
}

\begin{abstract}
Jelen tanulmányban a szerzö a Freinet pedagógia elkötelezett híve és müvelöjeként a Freinet pedagógussá válás sajátos útját kutatja. Arra a kérdésre próbál választ keresni, hogy ezen kötelezö képzéshez és a végzettséget igazoló oklevélhez nem kötött pedagógia elsajátításában milyen tényezők, hatások játszhatnak szerepet a felsőfokú óvodapedagógusképzésben eltöltött idöszaktól kezdödöen az aktív pedagóguspályán kínálkozó továbbképzési lehetőségeken át. A felsőoktatás mai szemszögéből nézve foglalkozik a Freinet pedagógia központi fogalmaival, alapelveivel, különös tekintettel az oktatási gyakorlatban megvalósitható tanulás- és tanitásszervezési szemléletmódra, alkalmazási lehetöségekre. Majd a Freinet mozgalom létrejöttének rövid ismertetését követöen bemutatja a magyarországi Freinet találkozók szellemiségét és gyakorlatát, amely a Freinet pedagógia iránt érdeklödö illetve már elkötelezett pedagógusok szakmai önképzés formájának szintere és bázisa.
\end{abstract}

\section{Bevezető}

Az 1989-es politikai fordulatot megelőző és követő néhány évben, azaz közel húsz éve bontakoztak ki Magyarországon az alternatív pedagógiai irányzatok, és az ezt követő időszakban jelentek meg a felsőfokú pedagógusképző intézményekben az alternatív pedagógiákat bemutató stúdiumok, és azok megvalósítására felkészítő gyakorlati-szakmai kurzusok. A teljesség igényére való törekvés nélkül megemlíthető a németországi kooperációval, Mesterházy Zsuzsa és Vekerdy Tamás közremüködésével hazai keretek között induló Waldorf-tanárképzés az akkori Bárczi Gusztáv Gyógypedagógiai Tanárképzö Főiskolán, illetőleg az Alapítványi és Magániskolák Egyesülete keretében Békési Ágnes nevéhez kötődő Alternativ Tanárképzö Stúdium Budapesten. (Horváth, 1991)

Az 1989-90-es tanévtől kezdődően a Soproni Óvóképzö Főiskola gyakorló óvodájában találkozhattak az óvodapedagógus hallgatók Célestin Freinet (18961966) munkásságának első magyarországi óvodai adaptációjával. A határmenti város óvóképzője nem pusztán a hallgatóknak kínált betekintést ebbe a reformpedagógiai alapokon nyugvó alternatív pedagógiába, hanem az itt szervezett intenzív továbbképzések és Freinet találkozók több száz pedagógust vonzottak az ország számos régiójából, akik élve a pedagógiai pluralizmus és a módszertani szabadság 
lehetőségével befogadónak mutatkoztak a „forradalminak” ható gyermek- és tevékenységközpontú pedagógiák iránt.

Célestin Freinet által közel száz éve megalkotott természet- és életközeli pedagógiai koncepció egyik kivételes sajátossága, hogy nem szigorúan deklarált elvekkel és módszerekkel körülbástyázott rendszer, hanem nyitott, dinamikus alapelvekkel, innovatív technikákkal rendelkező rugalmasan alkalmazható szellemiség. Vannak pillérei, amelyekbe kapaszkodni lehet, de nincsenek korlátai, amelyek beszabályozzák. Két fentebb már említett alapelve, a természet- és az életközeliség folyamatosan biztosítja a szellemiség megújulását, egyben feltételezi a változó világhoz, a környezethez való folytonos alkalmazkodást; a pedagógusokból pedig előhívja a permanens szakmai megújulás, önképzés igényét. A harmadik alapelv - a szabad önkifejezés - lehetővé teszi a gyermek személyiségének és a pedagógus egyéniségének, módszertani szabadságának harmonikus kiteljesedését. Ezért joggal mondható, hogy a Freinet-pedagógia csak alkotó pedagógusok kezében müködik igazán (Zsámboki, 1993).

A Waldorf- és a Montessori-pedagógusképzés alapját és kritériumát jelentő szemináriumokkal, tanfolyamokkal ellentétben a Freinet-pedagógusokkal szemben nincsenek szigorúan deklarált, kényszerü elvárások. Ahhoz, hogy valaki Freinetpedagógussá váljon, illetve pedagógiai munkájában Freinet elemeket alkalmazzon, nincs és soha nem is volt szükség szakmai végzettséget igazoló papírosra. Akkor pontosan hol és hogyan válik valaki Freinet-pedagógussá? - tehetjük fel mindezek után joggal a kérdést.

A pedagógusképző intézmények hallgatói napjainkban leggyakrabban a neveléstörténeti kurzusokon, illetve az alternatív pedagógiákat bemutató stúdiumok alkalmával találkozhatnak elöször Célestin Freinet koncepciójával, mint egy lehetséges - reformpedagógiai alapokon nyugvó - gyermek- és tevékenységközpontú elképzelés egyikével. A Soproni Óvóképző Főiskola jogutódjaként múködő Nyugatmagyarországi Egyetem Benedek Elek Pedagógiai Karán tanulmányaikat végző óvodapedagógus hallgatók már a tanulmányaik alatt, a gyakorlati képzés keretei között bepillantást nyerhetnek egy Freinet-szellemü óvodai csoport életébe, és amennyiben kedvet kapnak hozzá, később maguk is Freinet-pedagógussá válhatnak.

Jómagam - korábbi Freinet-s gyakorlatvezető óvodapedagógusként, és jelenleg is Freinet pedagógiai alapelveket valló és alkalmazó oktatóként - aktív részt szeretnék vállalni abban, hogy ne csupán az óvodában eltöltött gyakorlati képzésben jelenjenek meg a francia néptanító kidolgozott innovatív pedagógiai alapelvek és technikák, hanem a felsöfokú oktatás elméleti kurzusainak kooperatív és konstruktiv tanulás- és tanitásszervezö gyakorlatába is beépüljön ez a szemléletmód.

Tanulmányom első részében az imént megfogalmazott célkitűzés érdekében szeretném bemutatni a Freinet-pedagógia alapelveit a mai magyar felsőoktatás szemszögéből, bizonyítandó, hogy a több mint fél évszázados gondolatok ma is aktuálisak és kívánatosak az óvodapedagógus hallgatók gyermek- és tevékenység- 
központú szemléletének alakításában. Hiszem és vallom, hogy a kurzusok során elsajátítandó tartalom és az elsajátításhoz szükséges eljárások, módszerek maguk is a „tananyag” részét képezik, ezért alkalmasak arra, hogy már a képzés szakaszában inspirációt jelentsenek egyes hallgatók számára a Freinet-pedagógussá váláshoz.

Tanulmányom második felében a pedagógus-továbbképzés sajátosan Freinet-s módját kívánom bemutatni a Freinet mozgalom létrejöttének rövid ismertetésével és a magyarországi Freinet találkozók szellemiségének és gyakorlatának vázolásával.

\section{A Freinet pedagógia központi fogalmai, alapelvei a felsőoktatás mai szemszögéből}

Célestin Freinet pedagógiai koncepciójának központi fogalmait, alapelveit írói termékenységének legaktívabb korszakában, a második világháború alatti időszakban vetette papírra. Később nyomtatásban is megjelent müveiben - pl. L'Ecole Moderne Francaise, Les techniques Freinet de l'École Moderne ${ }^{1}$ - megfogalmazódik a hagyományos, tantervszerü formában, racionális keretek közé szorított oktatási koncepció elutasítása és körvonalazódnak az érdeklődésen alapuló, hatékony tanulási környezet és technikák megszervezésének központi fogalmai, melyeket az alábbiakban részleteznék.

Freinet koncepciójának elemei deklarált részei napjaink oktatási programjainak, de a gyakorlati megvalósítás sok esetben hiányos vagy egyáltalán nem érhető tetten. Ezért van jelentősége rendszerbe foglalva és a lényeges elemek kiemelésével ismét ráirányítani a figyelmet e korszerủ tanulás-felfogás elméleti és a felsőoktatásban is követhető gyakorlati sajátosságaira.

\section{A munkálkodás pedagógiája (,Pédagogie du travail”)}

Freinet pedagógiájában központi szerepet kap a munkálkodás, mint természetes gyermeki állapot, s vele szemben ellenpólusként fogalmazódik meg a természetellenes tétlenség. Épít a gyermekben rejlö ösztönös erőfeszítésre, alkotásvágyra, melynek során a gyermek a saját maga által kitüzött célok érdekében teljesítőképessége legszélső határáig eljuthat.

A munkálkodás pedagógiája alatt mai szóval alkotás- és tevékenység-orientáltságot érthetünk. A hallgatók kezdeményezői és szervezői legyenek tanulási folyamataiknak, melynek középpontjában a saját élményü tanulás, az alkotás és tevékenység áll. Ezen tényezők segítségével kialakíthatók a későbbi pedagógiai munkában olyannyira kívánatos gyermek- és tevékenységközpontú szemlélet keretei és módszertani eszközei. A hallgatói munkát csoportos formában, együttmüködésen alapuló, megosztott felelősség mentén érdemes szervezni és a mindennapok

\footnotetext{
${ }^{1}$ A Francia Modern Iskola (1946) ill. A Modern Iskola technikái (1964; 1982) Tankönyvkiadó, Bp.
} 
gyakorlatában megvalósítani. Így a tradicionális - és gyakran elkerülhetetlen frontális óravezetéssel szemben a kooperatív tanulásszervezésre építő órák esetében a hallgatói tevékenység elsőrangú szerepet kaphat.

Fentebb hangsúlyozott tevékenység-központúság megvalósítására szolgál - a felsőoktatás gyakorlatában is egyre nagyobb teret hódító - projektmódszer. A pedagógiai projekt nem Célestin Freinet találmánya, hiszen eredete régebbi időkre nyúlik vissza. ${ }^{2}$ Ugyanakkor a XX. század elején megjelenő reformpedagógiák - köztük a Freinet-pedagógia is - szívesen alkalmazta, mint a praktikus logikát követő valóságos élettevékenységekböl fakadó komplex ismeretszerzés lehetőségét. Ezen tanulási folyamat során kibontakozó ismeretek - feladat-orientáltságukból fakadóan nem szoríthatók szigorúan diszciplináris keretek közé, hiszen kevéssé megtervezhetö, hogy a tantárgyak mely elemeit mozgósítja. Az ismeret ennek megfelelően tudományos marad, de az ismerethez jutás logikája szakít a tradicionális iskolai megismerés alapvetően passzív befogadó voltával (Hortobágyi, 1991).

A projektmódszer lehetővé teszi a középpontjába helyezett problémakör jelenségeinek komplex vizsgálatát, az összefüggések feltárását, egyes kiemelt részterületekben való elmélyülést, változatos kutatási módszerek alkalmazását, valamint a résztvevők közötti tevékeny együttmüködést. Nem ritkán olyan hallgatói képességeket, pedagógusi kompetenciákat hív elő és fejleszt, melyek egyáltalán nem illeszthetők be tantárgyi keretek közé; jelentőségük akár később, a pályakezdés szakaszában juthat érvényre.

\section{Kooperativ tanulás (,, Travail coopératif”)}

Freinet pedagógiájának alapelveiben megfogalmazza tanítási technikáiról vallott nézeteit: [A gyermek] „Kedveli viszont az egyéni vagy csoportmunkát egy együttmüködő közösség keretein belül. A csoportban vagy közösségben/szövetkezetben végzett munka nem azt jelenti, hogy mindenki ugyanazt csinálja. Ellenkezőleg: Az egyénnek maximálisan meg kell őriznie az egyéniségét a közösség szolgálatában." [...] „A gyerekek megértik, elfogadják, gyakorolják, maguk szervezik (életüket), ha szükségesnek tartják." (Freinet, 1979/1994, 55. o.)

A kooperatív tanulás mai értelmezésében fenti gondolatokkal összhangban a tudáskonstruálás lehetőségének megteremtése, a szociális kompetenciák alakítása, valamint az önszabályozó tanulási motívumok fejlesztése a felsőoktatásban is egyidejü és egyenrangú cél. Nélkülözhetetlen elem az épitő egymásrautaltság, melynek során az egyes hallgatók, hallgatói csoportok valóban érdekeltek egymás sike-

\footnotetext{
${ }^{2}$ A XVIII. század közepén a párizsi és itáliai építészeti akadémiákon projekteknek nevezték a nagyobb építkezési vállalkozások azon részleteit, amelyeket a felsőbb évfolyamokra járó diákok önálló kidolgozásra kaptak meg. Az USA-ban a 19. század közepén hasonló értelmezéssel terjed el a projekt fogalma az építészeti, technikai, mezőgazdasági és müvészeti főiskolákon, amelyekben a záróvizsga feltételéüI szabták egy-egy gyakorlati feladat megoldását (Hortobágyi, 2002).
} 
rében. A közös célt csak az egyéni teljesítmények felelösségteljes elvégzése és optimális összehangolása hozhatja létre. Az egymásrautaltság erősödésével a kooperatív magatartás is fejlődik, így a közösségépités a tanulási folyamat szerves részét alkotja, mely segíti a hallgatókat a későbbi pályaszocializáció és a társadalmi integráció során.

Fentieknek megfelelően a kooperatív tanulásszervezésben az oktatói szerep más dimenzióban nyer értelmet: facilitátor jellegü, célja az együttmüködő ösztönzés, szükség esetén segítségnyújtás, tanácsadás. Nem ritkán megkívánja az oktatási keretek, térszerkezet radikális átalakítását is, hiszen a hagyományos tantermi elrendezés szük teret biztosít a kooperációra, a mühely-jellegü munkára. Freinet osztályterme az 1920-as években, tanítói pályája kezdetén szintén sokkal inkább mühelyre hasonlított. Az asztalokat és székeket éppen az aktuális tevékenységnek megfelelően rendezték el. Az addig központi szerepet játszó tanári asztal a tanterem közepére állítva a szemléltetésre, bemutatásra szánt tárgyak kiállítóhelyeként szolgált (Mészáros, Németh és Pukánszky, 2005).

A felsőoktatásban is kívánatos, hogy az oktatási színterek át- és elrendezése ne az önmagáért való rendet szolgálja, hanem a tevékenységek sokféleségének megvalósíthatóságát és az egymás közötti kommunikációt segítse elö. Az ilyen jellegü foglalkozásokra való felkészülés az oktatótól a szokásosnál is több szellemi befektetést igényel, a megvalósítás pedig alapos előkészületeket, szervezőmunkát és megosztott figyelmet kíván, mely kezdetben - tapasztalataim szerint - nem mindenesetben társul kellő hallgatói lelkesedéssel, hosszú távon azonban gyümölcsöző kapcsolatot és munkát eredményez.

\section{Kísérletezö próbálkozás és tévedés (,, Tâtonnement experimental”)}

Egy ókori keleti mondás szerint: „Amit hallok elfelejtem, amit látok, arra emlékszem, amit csináltam, azt tudom is". Fenti mondással ellentétben napjaink hagyományos oktatási gyakorlatában még mindig a tanulás kognitív formája áll elötérben. A verbálisan történő tananyag-feldolgozás mellett, a tudás ellenőrzése és értékelése többnyire az ismétlö jellegü visszamondás eredményességét jelenti, nem tulajdonítva kellő jelentőséget az aktivitásnak, és az „értékes" tévedés lehetőségének. A „kísérletező tapogatózás” Célestin Freinet pedagógiájában a gyermek természetes kíváncsiságára építő, abból táplálkozó ismeretelsajátítási mód, amelyben a tudás átadása helyett a felfedezésből származó tapasztalatszerzés, a kutatás, a gondolkodási mód elsajátítása a legfőbb cél.

A felsőoktatásban a gyakorlati stúdiumok színterén hasonlóképp a készen kapott ismeretek elfogadása helyett az egyéni kísérletezés, tapasztalatszerzés és tudáskonstruálás aktivizálása jelentheti a tanulási folyamat célját. Nem pusztán valamely célnak vagy eszmének alárendelt tudatosság révén elöírt tankönyvi igazságok, hanem a saját vizsgálatok, tapasztalatok, az előzetes tudás és a nézetek, valamint a valóság 
együttesen határozza meg a hallgatók gondolkodását. Ennek megfelelően kiemelt jelentőségü, hogy a hallgatók - tanegységekre tagoltság helyett - komplex, interdiszciplináris és egyben gyakorlati pedagógiai tudást szerezzenek a képzés során.

A tanulásról alkotott konstruktivista szemlélet ezzel szemben épít a hallgatók elözetes - deklaratív jellegü - tudására, ,, amelynek elsajátitása természetes közegben, életszerü tapasztalatok révén történik, és így alkalmazása is természetes könnyedséggel és hatékonysággal valósul meg” (Csapó, 2002, 40. o.). Hozzájárulva a döntésvállalást segítő problémafelismerő és -megoldó gondolkodás fejlődéséhez, a gyakorlatban alkalmazható tudás kialakulásához.

\section{Természetes módszer (,,Méthode naturelle”)}

Freinet kitárta az iskola kapuit arra az életre, amely a gyermekeket közvetlenül körülvette. Az élményekkel átszőtt élettapasztalatokat az iskolában feldolgozták, beépítették a tanulmányaik folyamatába. Napjainkban a gyermekkori tanulás tapasztalatra épülő jellegét szintén a gyermeket körülvevő társadalmi-természeti környezettel való harmonikus és tudatos együttélés biztosítja.

A „természetes” tanulás alapját felnőttkorban előzőeken túlmenően a tanuló személy egyedi, sajátos tanulási folyamata, tanulási stílusa, kialakult tanulási stratégiái képezik, melyben kiemelt szerepet játszik a folyamatos reflexió illetve a tanulási folyamat tudatosítása és tudatosulása, a metakogníció. Gondolkodásunk metaszintü összetevői az önreflexió megjelenésétől folyamatosan föszerepet kapnak az értelmi fejlődésben, ezért tekinthető többek között a felsőfokú oktatás céljának és eszközének is a gondolkodás stratégiai szintü komponenseinek felszabadítása. A problémamegoldás és a kutató feladatok bármely tanegység esetében jó alkalmat szolgáltatnak a metakognitív stratégiák fejlesztésére (Csíkos, 2007). Ezen stratégiák - az új tudás kapcsolása a már meglévőhöz, a gondolkodási stratégia tudatos megválasztása, az értelmi folyamat tervezése, nyomon követése és értékelése - az oktatók pedagógiai „eszköztárának” szerves részét képezik. Alkalmazásuk során feltárhatók a problémahelyzetek, felkutathatók az alternatív megoldások, a hallgatók számára nyomon követhető, szabályozható és megítélhető saját gondolkodásuk. A gondolkodásban jelen lévő feladatmegoldó stratégiák sokszínűségének kialakításával és fenntartásával, illetve a reflektív szemléletmód alapozásával valósítható meg a felsőoktatásban is a „tudatosan természetes” tanulás pedagógiája.

\section{Érdeklödés-központúság (,, Complexe d'intérêt”)}

„Az értelem nem magtár, amit megtöltünk, láng, amelyet szítani kell.” - írja Freinet az 1930-as években egy népoktatási lapban (Veress, 1966, 410. o.). Az érdeklődés, a kíváncsiság és a tudásvágy azonban nem csupán gyermekkorban alkotják a tanulási folyamat mozgatórugóját. Az ifjú- és felnőttkori tanulásnak egyaránt kulcsfontosságú tényezői a belülről fakadó (intrinsic) motiváció, a tudásvágy, a folyamatos 
önképzésre való igény és nem utolsó sorban a „hasznossági elv”. A felsőoktatásban részt vevő hallgatók akkor motiváltak igazán a tanulásra, ha maguk is kedvet és okot éreznek rá, illetve, ha egzisztenciálisan megalapozott távlati cél vezérli őket. A tanulás előremozdítója még ezen iskolafokon is az élményközpontúság és a siker. A hallgatók saját öntevékeny aktivitására alapozott tanulási folyamat, a tevékenységek szervezésénél hangsúlyos problémaközpontúság, a kreativitás és a diverzív gondolkodásra ösztönző csoportmunka együttesen létrehozhatja az optimális, tanulásra irányuló aktivációs szintet (flow-élmény, vö. Csíkszentmihályi, 2001). Ez az állapot az egyik legerősebb motivációs késztetés, melynek következtében a tanulás hatékonysága optimális, a különböző tanulási motívumok egyidejüleg müködtethetők.

Az élmény-vagy tevékenységközpontú tanulásszervezés alkalmazása a felsőoktatás színterén a természetes emberi tanulási formák újra felfedezését és szervezett oktatási keretekhez való adaptálását jelenti, illeszkedve a spontán emberi megismerés sajátosságaihoz, és alkalmazkodva az információs és kommunikációs „forradalom" nyomán keletkezett megváltozott tanulási környezethez.

\section{Demokrácia (,Démocratie”)}

Freinet szintézis-pedagógiájában megjelenő demokratikus-liberális alapvetés, a szabadság és az öntevékenység hangsúlyozása, az egyéni és közösségi interakció szerepe már a korábbi reformpedagógiai elgondolásokban pl. Maria Montessori, John Dewey koncepciójából is kiolvasható volt. A francia néptanító Modern Iskolájában azonban a cselekvés szabadsága és a véleménynyilvánítás biztosítása demokratikus alapokon nyugvó, egyenlő szabadságjogokkal és kötelezettségekkel müködő osztályközösséget kívánt. A tanulóközpontú, demokratikus pedagógiai szemlélet kialakítása, demokratikus alapértékek, a tolerancia, a nyitottság közvetítése, a hallgatók autonómiájának, döntéshozó kompetenciájának fejlesztése napjaink felsőfokú pedagógusképzésében is nélkülözhetetlen eszköz és cél. Életünkben, társas kapcsolatainkban, munkahelyi környezetünkben a szaktudás mellett elengedhetetlen a kommunikációs készségek fejlettsége, az együttmüködésre, a toleranciára való alkalmasság. A szociális kompetenciák megfelelő fejlettségi szintje a társadalmi beilleszkedés és a demokratikus együttélés elengedhetetlen feltétele, melyeknek alakulásában kiemelt szereppel bír a segítően kritikus, nyitott légkör, a támogató együttmüködés és az egymás különbözőségeire épített tanulásszervezés. Az együttmüködést, közös döntéseket, szabályok alkotását, felelősségvállalást feltételező hallgatói kooperáció során egyaránt kimunkálódhatnak az eredményes, kölcsönösen elfogadható, hiteles és célravezető kommunikáció formái.

Fentiek alapján összegezhető, hogy a francia néptanító által több mint fél évszázada megalkotott szintézis-pedagógia alapelvei napjaink felsőfokú oktatásában is mérvadónak tekinthetők, aktualizálhatók, mert megteremtik és jól szolgálják a kooperatív és konstruktív szellemiséget kívánó tanulás és tanítás elméleti és gyakor- 
lati kereteit. A következőkben az óvodapedagógus-képzést követő sajátosan Freinet-s önképzési lehetőségeket szeretném vázolni.

\section{A pedagógus-továbbképzés színterei: a Freinet mozgalom és a Freinet találkozók}

A hazai vagy külföldi pedagógusképzések lajstromában nincsenek és soha nem is voltak Freinet-pedagógusokat képző intézmények, kurzusok. Ennek a pedagógiának nyitottságát, megújulását ugyanis egy lelkes és elkötelezett pedagógusokból alulról szerveződő és a gyakorlathoz közel álló mozgalom tudta és tudja megőrizni évtizedek hosszú során át. A Freinet-szellemiség elkötelezett híveivé azok váltak és válnak igazán, akik a belülről fakadó érdeklődésből és igényből merítve késztetést éreznek arra, hogy részletesen megismerjék gyermekközpontú szellemiségét, rendszerét, magukévá tegyék alapelveit és változatos technikáit, miközben életre szóló élményekkel gazdagodhatnak egy-egy hazai vagy külföldi konferencián, Freinet találkozón.

A nemzetközi mozgalom gyökerei az 1920-as évek közepéig nyúlnak vissza, amikor Célestin Freinet iskolaközi levelezésekből induló kapcsolatokból megalakította a Laikus Világi Tanitók Szövetkezete nevü összefogást, a CEL-t (Cooperative de l' Enseignement Laic). Később, a II. világháborút követően a széleskörü érdeklődésnek köszönhetően a CEL-t tartalmában és eszmeiségében megújulva felváltotta a Modern Nevelés Szövetkezeti Intézete, az ICEM (Institut Cooperatif de I’École Moderne). Ezzel a lendületes pályakezdéssel egy fiatal néptanító megalapozta a máig is élö, nemzetközi kapcsolatokat felölelő pedagógiai mozgalmat. 1957-ben, még Freinet életében létrejött a FIMEM (Fédération Internationale du Movement de l'Ecole Moderne), a Modern Iskolák Mozgalmainak Nemzetközi Szövetsége, mely kb. 35-40 olyan ország nemzeti mozgalmát egyesíti még ma is, amelyek magukénak vallják a Freinet pedagógia elveit és gyakorlatát. Tagszervezetei múködnek a világ szinte minden táján, Európától Ázsiáig, Amerikától Afrikáig egyaránt.

A FIMEM 1968 óta minden második évben nemzetközi kongresszust szervez, ez a RIDEF (Rencontre Internationale des Éducateurs Freinet), vagyis a Freinet Nevelök Nemzetközi Találkozója ${ }^{3}$. A résztvevők egyrészt Freinet-pedagógusok, másrészt olyan tanárok, kutatók, diákok, szimpatizánsok a világ minden tájáról, akik azért jönnek, hogy egymástól tanulva elmélyítsék, alkotó módon újrateremtsék pedagógiai ismereteiket, beszámoljanak tapasztalataikról, vagy megismerkedjenek a Freinet-technikákkal és a mozgalommal. A multikulturalitás és kollegialitás jegyében több száz pedagógus vesz részt a találkozókon, ahol szemináriumok, alkotó mühelyek, viták, és sok egyéb tevékenység során kooperatív csoportmunká-

\footnotetext{
${ }^{3}$ A legutóbbi RIDEF 2010. július 20-29. között került megrendezésre a franciaországi SaintHerblain-ben.
} 
ban ismerkedhetnek a különböző országokban folyó gyakorlattal. A kezdőként ide érkezők az elméleti előadások, kurzusok helyett egymástól tanulva, kísérletező módon próbálkozva, öntevékeny módon ismerkedhetnek meg a francia néptanító pedagógiájával.

A nemzetközi továbbképzések szellemiségének megfelelően, azzal azonos módon müködnek a hazai Freinet találkozók is, melyek nyitányának az 1980-as évek elején kibontakozó magyarországi Freinet mozgalom tekinthető. 1982-ben a nemzetközi Freinet mozgalom Eszperantó Bizottsága tíz napos pedagógus találkozót szervezett Magyarországon, melyet követően a 80-as évek végére a magyarországi Freinet mozgalom kiszélesedését jelző, több alulról szerveződő kezdeményezés is elindult. ${ }^{4}$

1990. év januárjában 31 alapító taggal bejegyzésre került a Magyar Freinet Alapitvány, amely müködése alatt a Freinet találkozók fö szervezője és anyagi támogatója volt. Majd egy évtizeddel később 2001-ben létrejött a Magyarországi Freinet Egyesület, mint közhasznú szervezet, a magyarországi Freinet mozgalom munkájának segítése, támogatása, illetve az akkreditált országos továbbképzések szervezése céljából.

A Freinet pedagógiájának hazai adaptációjából fakadó sokszínủ szakmai tapasztalat megosztásának igénye hívta életre 1990-es évektől kezdődően a helyi bemutatókat, országos táborokat, szakmai összejöveteleket, továbbképzéseket, melyeknek a modellje sajátos elemeket tartalmaz más továbbképzési rendszerekhez viszonyítva. Éppen azt a természetes utat és módot követik a pedagógus szakmaiságának kibontakozásában, amelyet maga Freinet is vallott: „Az ember nem hallgatva és ismételve müvelődik többé, hanem cselekedve" (Miklósvári, 1967, 10. o.) Ezeknek az alkalmaknak sajátságos megvalósulására jobban illik a találkozó, a mühelymunka elnevezés. Segítő, megértő, inspiráló és befogadó légkör hatja át, amely az önmegvalósítást teljes élménnyé teszi. Fontos a belülről fakadó indíték, hogy a pedagógus akarja, keresse a megújulás lehetőségeit. Esetleg maga kezdeményezze, szervezze, így felelősséget érez az általa választott program eredményes megvalósulásában. A program tematikája az élet sokszínűségére, aktualitásaira reflektálva teremt lehetőséget a pedagógusok szakmai eszmecseréjére, a permanens önképzésre (Zsámboki, 1993).

A négy-öt napos rendezvény évenként változó helyszínen kerül megrendezésre, melyet minden alkalommal az elöző találkozón vállal fel egy lelkes óvodapedagógus-közösség. A szervezés munkálatai között szerepel a központi téma kijelölése, a program részletes megtervezése, az alkalmas helyszín kijelölése és a mühelyvezetők felkérése. Műhelyvezetésre - előzetes egyeztetést követően - bárki jelentkezhet, illetőleg bárki ajánlható, aki vállalja, hogy három-négy napon át, délelöttön-

\footnotetext{
${ }^{4}$ 1988-ban Dombóváron került megrendezésre az első Freinet találkozó és szeminárium Galambos
} Rita és Horváth H. Attila szervezésében. 
ként a résztvevők együttműködésén, közös tevékenységén alapuló, alkotó-mühely jellegü munka során dolgoz fel egy - a találkozó központi motívumához kapcsolódó - témát.

A megérkezés napján keretjátékkal indul a program, melynek során kibontakozik a találkozó központi tematikája, rövid bepillantást nyerhetnek az érkezők a találkozó vidám, önfeledt hangulatába és a vendéglátó Freinet-s óvodapedagógusok mindennapjaiba. A keretjáték során a résztvevők kooperatív kiscsoportokban tevékenykednek, játszanak együtt, megkönnyítve az ismerős és még ismeretlen résztvevők számára a beilleszkedés nehézségeit.

A keretjátékot követő esti plénum az előzőeknél hivatalosabb megnyitóként funkcionáló esemény, amelynek alkalmával a résztvevők köszöntése, az aktuális szervezési és egyéb kérdések megbeszélése történik. A mühelyvezetők itt ismertetik röviden nagymühelyük témáját, várható programját, az együtt-tevékenykedés módját. A hivatalos köszöntő jellegzetes Freinet-s régió-vacsorával zárul, ahol az ország különböző pontjairól érkezők megvendégelik egymást saját tájegységük jellemző ételeivel.

A második nap reggelén induló nagymühelyek jelentik a találkozó pedagógiaiszakmai vázát. Délelőttönként adnak lehetőséget a feliratkozott $-\mathrm{s}$ végig együtt dolgozó - résztvevőknek a felkínált témában való elmélyülésre. A szemináriumszerü, projektként müködő vagy alkotómühely jelleggel szerveződő (vö. Horváth $H ., 1999$ ) közös tevékenység alapja az együttes élmény és a szabad önkifejezés, amely szerves része és inspirálója a Freinet pedagógusok szakmai önképzésének.

A délelőtti nagymühelyeket követően, délután szabadon választható és ,,átjárható" kismühelyekben folytatódik a munka, melynek során gyakorlatias jellegü, kreatív foglalkozások (pl. kézmüvesség, tánc stb.) keretében sajátíthatnak el az érdeklődők újszerü, praktikus technikákat, miközben lehetőség nyílik az egymás közti pedagógiai-szakmai tapasztalatcserére.

A több napos feltöltődést követően a mozgalmas találkozó vidám színes esttel zárul, ahol tartalmas, szórakoztató vagy épp elgondolkodtató müsorok, előadások, kiállítások keretében tekinthetnek be a résztvevők a többi nagymühelyben folyó munka eredményeibe, hangulatába.

\section{Záró gondolatok}

Az imént bemutatott Freinet találkozók szervezeti struktúrája, szellemisége biztosítja és egyben feltételezi is a pedagógusok aktív, tevékeny részvételét, alkotókedvét, kreativitását. Megkívánja tőlük, hogy olykor-olykor gyermekként kísérletezgetve, próbálkozva tanulják önmagukat, mérettessék meg szakmaiságukat a találkozó közössége előtt. Így válnak az évek során, az egész életen át tartó tanulás által olyan pedagógusokká, akik ihlető környezetet, változatos technikákat és élményközpontú 
tevékenységeket biztosítanak a gyermekek számára, akikben az önkifejezés vágya természetes módon ébred fel.

A találkozón átélt élményeket, tapasztalatokat a mindennapokba átültetve válnak a Freinet-pedagógusok a rájuk bízott gyermekek természetes, nyitott, humánus és ösztönzően kritikus társává, elősegítve a gyermeki személyiség harmonikus fejlődését, kiteljesedését, önmaguk megismerését. Gyermek és pedagógus kölcsönösen facilitálja egymást a közös alkotásra, munkálkodásra, megtapasztalva közben az emberi - természeti - tárgyi környezet felfedeznivaló csodáit, a születő gondolatok szárnyalását és korlátait, átélve a személyes felelősség érzését és súlyát.

\section{Irodalom}

Csapó Benő (2002): A tudáskoncepció változásai: nemzetközi tendenciák és a hazai helyzet. Új Pedagógiai Szemle, 2. sz. 38-45.

Csíkos Csaba (2007): Metakogníció. A tudásra vonatkozó tudás pedagógiája. Müszaki Kiadó, Budapest.

Csíkszentmihályi Mihály (2001): Flow - Az áramlat. Akadémiai Kiadó Zrt, Budapest.

Freinet, C. (1979/1994): A Freinet-pedagógia szemlélete. Új Pedagógiai Szemle, 5. sz. 53-55.

Hortobágyi Katalin (1991): Projekt kézikönyv. ALTERN füzetek 1. OKI, Iskolafejlesztési Központ, Budapest.

Horváth Attila (1991): Stratégiák az alternatív pedagógiában. In: Lukács Péter (1991, szerk.): Alternatív iskolák, alternatív pedagógiák Magyarországon. Kutatás közben sorozat OKI, Budapest. 26-29.

Horváth H. Attila (1999): A Freinet-találkozó mint sajátos önképzési rendszer. In: Horn Gábor, Horváth H. Attila, Sári Lajos, Vekerdy Tamás és Zágon Bertalanné (1999, szerk): Süss fel nap II. Kisgyermekkori modell-intézmények Magyarországon Soros Alapítvány, Pilisborosjenő. 118-123.

Mészáros István, Németh András, Pukánszky Béla (2005): Neveléstörténet. Bevezetés a pedagógia és az iskoláztatás történetébe. Osiris Kiadó Kft, Budapest.

Miklósvári Sándor (1967): Találkoztam Monsieur Freinet-vel. A tanitó munkája. 4. sz. 9-15. Veress Judit (1966): Celestin Freinet (1896-1966). Magyar Pedagógia, 3-4. sz. 406-421.

Zsámboki Károlyné (1993): Hogyan lesznek a Freinet pedagógusok? Iskolakultúra, 3-4. sz. $111-114$. 